\title{
PENERAPAN MODEL PEMBELAJARAN INKUIRI TERBIMBING BERBANTUAN CMAPTOOLS DALAM PEMBELAJARAN FISIKA UNTUK MENINGKATKAN KEMAMPUAN KOGNITIF DAN MEMPERTAHANKAN RETENSI SISWA
}

\author{
Agus Kurniawan \\ Guru SMA Negeri Kota Bandung \\ email: agus_kurniawan@yahoo.com
}

\begin{abstract}
ABSTRAK
Tujuan penelitian ini adalah untuk mengetahui perbedaan peningkatan kemampuan kognitif dan daya tahan retensi siswa pada materi ajar listrik arus searah antara kelas yang menerapkan model pembelajaran inkuiri terbimbing berbantuan CmapTools dan kelas yang menerapkan model pembelajaran inkuiri terbimbing tanpa bantuan CmapTools. Penelitian ini menggunakan desain penelitian randomized control group pretest-posttest design dengan pemberian posttest sebanyak tiga kali dalam selang waktu antara posttest selama tujuh hari (satu pekan). Sampel dalam penelitian ini adalah siswa-siswi kelas X-2 dan X-3 di salah satu SMA Negeri di Kota Bandung dengan jumlah masing-masing 38 dan 36 orang. Hasil penelitian menunjukkan bahwa skor rata-rata gain yang dinormalisasi $<\mathrm{g}>$ pada kelas yang menggunakan model pembelajaran inkuiri terbimbing berbantuan CmapTools sebesar 0,68 , sedangkan skor rata-rata gain yang dinormalisasi $<\mathrm{g}>$ pada kelas yang menggunakan model pembelajaran inkuiri terbimbing tanpa bantuan CmapTools sebesar 0,54. Meskipun, kriteria gain yang dinormalisasi $<\mathrm{g}>$ untuk kedua kelas masuk pada kriteria sedang, namun berdasarkan uji beda rata-rata, pada taraf kepercayaan 95\% (signifikansi 0,05) hasil penelitian menunjukkan bahwa model pembelajaran inkuiri terbimbing berbantuan CmapTools secara signifikan dapat lebih meningkatkan kemampuan kognitif siswa dibandingkan model pembelajaran inkuiri terbimbing tanpa bantuan CmapTools. Selain itu, hasil penelitian juga menunjukkan bahwa penerapan model pembelajaran inkuiri terbimbing berbantuan CmapTools dapat lebih mempertahankan retensi siswa pada materi ajar listrik arus searah dibandingkan dengan penggunaan model pembelajaran inkuiri terbimbing tanpa bantuan CmapTools.
\end{abstract}

Kata kunci: guided inquiry learning model assisted Cmap Tools, cognitive ability, and students' retention.

\section{ABSTRACT}

The purpose of this study was to determine differences of the increase of cognitive abilities and students' retention durability on material of direct current electricity between the classes that implement guided inquiry learning model assisted CmapTools and classes that implement guided inquiry learning model without the CmapTools. The reaserch design used in this research is randomized control group pretest-posttest design with posttest administration three times in the interval between the posttest for seven days (one week). The samples in this study were the students of class X-2 and X-3 in one of high schools in the city of Bandung with the amount of each class is 38 and 36 students'. The results showed that the average scores are normalized gain $\langle g>$ in class using guided inquiry learning model assisted Cmap Tools of 0.68, while the average score is normalized gain $<g>$ in class using guided inquiry learning model without assistance Cmap Tools of 0.54. Although, the normalized gain $\langle g\rangle$ criteria for both classes entry in the medium criteria, however, different test based on the average, at 95\% confidence level (0.05) the results of the study indicate that the guided inquiry learning model can significantly aided Cmap Tools more improve students' cognitive abilities compared guided inquiry learning model without the help Cmap Tools. In addition, the results of the study also showed that the application of guided inquiry learning model assisted Cmap Tools can be further aided to maintain students' retention in teaching materials direct current electricity compared to the use of guided inquiry learning model.

Keywords: guided inquiry learning model assisted Cmap Tools, cognitive ability, and students' retention.

\section{PENDAHULUAN}

Mata pelajaran fisika merupakan salah satu bagian dari Ilmu Pengetahuan Alam (IPA) yang diadakan dalam rangka mengembangkan kemampuan berpikir dalam menyelesaikan masalah yang berkaitan dengan peristiwa sekitar, baik secara kualitatif maupun kuantitatif, serta dapat mengembangkan keterampilan dan sikap percaya diri. Hal 
ini sejalan dengan beberapa tujuan mata pelajaran fisika di tingkat SMA/MA yang disebutkan bahwa mata pelajaran fisika bertujuan agar siswa memiliki kemampuan memupuk sikap ilmiah yaitu jujur, obyektif, terbuka, ulet, kritis dan dapat bekerjasama dengan orang lain. Selain itu, pada butir yang lainnya dikatakan bahwa mata pelajaran fisika bertujuan agar siswa menguasai konsep dan prinsip fisika serta mempunyai keterampilan mengembangkan pengetahuan, dan sikap percaya diri sebagai bekal untuk melanjutkan pendidikan pada jenjang yang lebih tinggi serta mengembangkan ilmu pengetahuan dan teknologi.

Dari uraian di atas tampak pada butir terakhir bahwa penyelenggaraan mata pelajaran fisika di tingkat SMA/MA dimaksudkan sebagai wahana atau sarana untuk melatih para siswa agar dapat menguasai pengetahuan, konsep dan prinsip fisika. Dalam prosesnya pembelajaran fisika bukan hanya menekankan pada penguasaan konsep saja (konten) tetapi juga seyogyanya mengandung keempat hal yaitu: konten atau produk, proses atau metode, sikap, dan teknologi sehingga pemahaman siswa terhadap fisika menjadi utuh dan dapat berguna untuk mengatasi permasalahanpermasalahan yang dihadapinya (Cain dan Evan dalam Depdiknas, 2008: 21). Konten atau produk, berarti bahwa di dalam fisika terdapat fakta-fakta, hukum-hukum, prinsipprinsip, dan teori-teori yang sudah diterima kebenarannya. Proses atau metode, berarti fisika merupakan suatu proses atau metode untuk mendapatkan pengetahuan. Sikap, berarti fisika dapat mengembangkan sikap ilmiah seperti tekun, teliti, terbuka dan jujur. Teknologi, berarti fisika terkait dengan peningkatan kualitas hidup.

Dilihat dari tujuannya tersebut, mata pelajaran fisika sangat baik bagi siswa jika dapat dilaksanakan sesuai dengan yang diharapkan. Namun pada kenyataannya, yang terjadi di lapangan masih belum sesuai dengan tujuan yang diharapkan. Hal ini dapat dibuktikan dengan hasil studi pendahuluan di salah satu SMA Negeri di kota Bandung dengan cara menyebarkan angket kepada siswa, wawancara lansung dengan guru mata pelajaran fisika, dan memperhatikan proses pembelajaran di kelas.

Dari data hasil penyebaran angket kepada beberapa siswa menunjukkan bahwa fisika termasuk mata pelajaran yang kurang disukai siswa. Hanya $26,41 \%$ siswa yang menyenangi fisika, selebihnya 73,59\% menjawab tidak suka. Alasan siswa tidak menyukai fisika karena siswa beranggapan bahwa dalam pelajaran fisika terlalu banyak rumus yang dihapalkan sebesar 35,90\%, metode pembelajaran yang membosankan sebesar 53,85\%, dan kurang menyukai pelajaran hitungan sebesar 10,26\%. Kemudian, dari hasil penyebaran angket pun diperoleh $52,83 \%$ siswa menganggap fisika sebagai pelajaran yang sulit, $43,40 \%$ siswa yang menganggap fisika sebagai pelajaran yang biasa saja tingkat kesulitannya, dan hanya $3,77 \%$ siswa yang menganggap fisika pelajaran yang mudah.

Dari data hasil wawancara dengan salah satu guru fisika, diketahui bahwa permasalahan yang sering dihadapi guru, yaitu siswa mudah lupa dengan materi pelajaran yang sudah diajarkan oleh guru. Hal ini tampak ketika setiap awal pembelajaran, guru selalu memberikan pertanyaan apersepsi, namun sangat sedikit atau tidak ada siswa yang mampu menjawab dengan benar sesuai dengan keinginan guru. Selain itu, metode yang sering digunakan guru dalam pembelajaran fisika di kelas adalah metode ceramah, diskusi/tanya jawab, dan drilling soal.

Adapun dari data hasil observasi pembelajaran fisika di kelas, diketahui bahwa guru lebih sering menjelaskan konsep dan memberikan penguatan pada akhir pembelajaran. Setelah penjelasan konsep, siswa diberi latihan soal dan salah satu siswa mengerjakan di papan 
tulis kemudian guru membahasnya.

Kajian pustaka dalam penelitian ini yaitu; dengan melihat data hasil studi pendahuluan yang telah dilakukan maka dapat dianalisis bahwa sebagian besar proses pembelajaran di kelas masih berpusat pada guru (teacher centered) dan bersifat transfer pengetahuan dari guru ke siswa saja sehingga pembelajaran pun hanya diarahkan kepada kemampuan siswa untuk menghafal informasi. Siswa lebih diarahkan untuk mengingat berbagai informasi tanpa memaknai informasi yang didapatkannya. Hal ini serupa dengan kondisi yang terjadi di beberapa sekolah lain, seperti yang dilaporkan oleh beberapa peneliti berdasarkan hasil pengamatan di salah satu SMA Negeri di kota Bandung (Rahmat, 2013), salah satu SMA Swasta di kota Bandung (Oktifiyanti, 2012), dan salah satu SMA Negeri di kota Pekanbaru (Norhamidah, 2013). Dari laporan ketiganya mengungkapkan bahwa proses pembelajaran yang terjadi di kelas lebih menekankan pada prosestransferpengetahuan darigurukesiswa, sehingga tidak menempatkan siswa sebagai pengkonstruk pengetahuan. Akibatnya ketika siswa lulus dari sekolah, mereka tidak mengetahui makna dari teori yang dihafalnya tersebut. Hal ini mengakibatkan rendahnya kemampuan kognitif siswa. Dalam prosesnya, pembelajaran fisika lebih sering menggunakan metode ceramah. Pembelajaran ini selanjutnya disebut sebagai pembelajaran tradisional karena memiliki ciri-ciri yang persis dengan ciri-ciri pembelajaran tradisional yang diungkapkan oleh Abraham dan Renher (1986 dalam Karim et all., 2007).

Dari beberapa data di atas dapat disimpulkan bahwa salah satu kemungkinan penyebab rendahnya kemampuan kognitif siswa dikarenakan pelaksanakan pembelajaran fisika di sekolah-sekolah masih menggunakan pembelajaran tradisional. Oleh karena itu, pembelajaran fisika lebih bersifat informatif yakni guru menyampaikan materi kapada siswa secara utuh dan kurang melibatkan siswa dalam proses pembelajarannya.

Selain itu, pembelajaran yang hanya berpusat pada guru dan kurang melibatkan siswa dalam proses pembelajarannya, dapat menyebabkan lemahnya retensi (daya ingat) siswa mengenai materi pelajaran yang sudah dipelajarinya. Retensi (daya ingat) siswa adalah banyaknya pengetahuan yang dipelajari oleh siswa yang dapat disimpan dalam memori jangka panjang dan dapat diungkapkan kembali dalam jangka waktu tertentu (Pranata dan Rose, 2007). Hal ini sejalan dengan hasil penelitian yang dilakukan Magnesen (dalam De Porter, 2000), bahwa kita mengingat $10 \%$ dari yang dibaca, 20\% dari yang didengar, 30\% dari yang dilihat, $70 \%$ dari yang dikatakan, dan 90\% dari yang dikatakan dan dilakukan.

Sehubungan dengan permasalahan tersebut maka perlu adanya upaya perbaikan proses pembelajaran agar siswa lebih banyak terlibat dalam pembelajaran. Dengan adanya keterlibatan siswa dalam proses pembelajaran akan memudahkan mereka menemukan dan memahami konsep-konsep yang dipelajarinya. Makin banyak siswa terlibat dalam proses pembelajaran, diharapkan semakin kuat retensi (daya ingat) siswa mengenai materi yang dipelajarinya dan diharapkan pula makin tinggi kemungkinan hasil belajar yang dicapainya (sebut kemampuan kognitif).

Salah satu model pembelajaran yang dipandang dapat membantu dan memfasilitasi untuk kemampuan kognitif siswa adalah model pembelajaran inkuiri. Terdapat beberapa jenis inkuiri yang dapat digunakan sesuai dengan keadaan siswa yang bersangkutan. Dengan melihat keadaan siswa yang terlihat pada studi pendahuluan maka jenis inkuiri yang cocok digunakan adalah inkuiri terbimbing. Istilah inkuiri terbimbing digunakan karena pada pelaksanaannya guru memberikan bimbingan atau petunjuk yang cukup luas kepada siswa dalam merencanakan 
eksperimen dan perumusan kegiatan.

Secara garis besar, proses pembelajaran berbasis inkuiri dapat dituangkan dalam lima tahapan (Gulo, 2002: 44), yaitu 1). mengajukan pertanyaan (permasalahan), 2) merumuskan hipotesis, 3) mengumpulkan data (eksperimen), 4) analisis data, dan 5) membuat kesimpulan.

Selain penggunaan model pembelajaran inkuiri terbimbing, salah satu upaya lainnya yang terbukti mampu untuk membantu meningkatkan kemampuan kognitif dan mempertahankan retensi siswa adalah metode pemetaan konsep. Dewasa ini telah dikembangkan suatu perangkat lunak (software) yang dapat membantu dalam pembuatan peta konsep yang disebut dengan CmapTools.

CmapTools merupakan sebuah software yang dikembangkan oleh Institute for Human and Machine Cognition (IHMC) yang dapat digunakan sebagai alat pemetaan konsep.
Dengan menggunakan CmapTools, siswa aktif mencari dan menganalisis informasi secara luas dari seluruh dunia. CmapTools merupakan perangkat lunak yang dapat terhubung dengan jaringan internet dimana siswa bersama-sama dibangun dan terhubung dengan CmapServer. Dengan CmapTools model pengetahuan visual diperkaya dengan sumber-sumber hypermedia (gambar, animasi, video, url html, dll).

Materi pembelajaran yang dikaji dalam penelitian ini ialah materi listrik arus searah, materi ajar ini dipilih karena merupakan materi ajar yang sangat dekat dengan fenomena yang sering ditemui siswa dalam kehidupan sehari-hari. Namun demikian, materi ini juga dapat dibilang materi yang abstrak sehingga pada kenyataannya tidak sedikit siswa mengalami kesulitan dalam mempelajari konsep-konsep dari materi ajar ini termasuk untuk menerapkannya dalam permasalahan sehari-hari. Oleh karena itu, diharapkan siswa mendapatkan manfaat

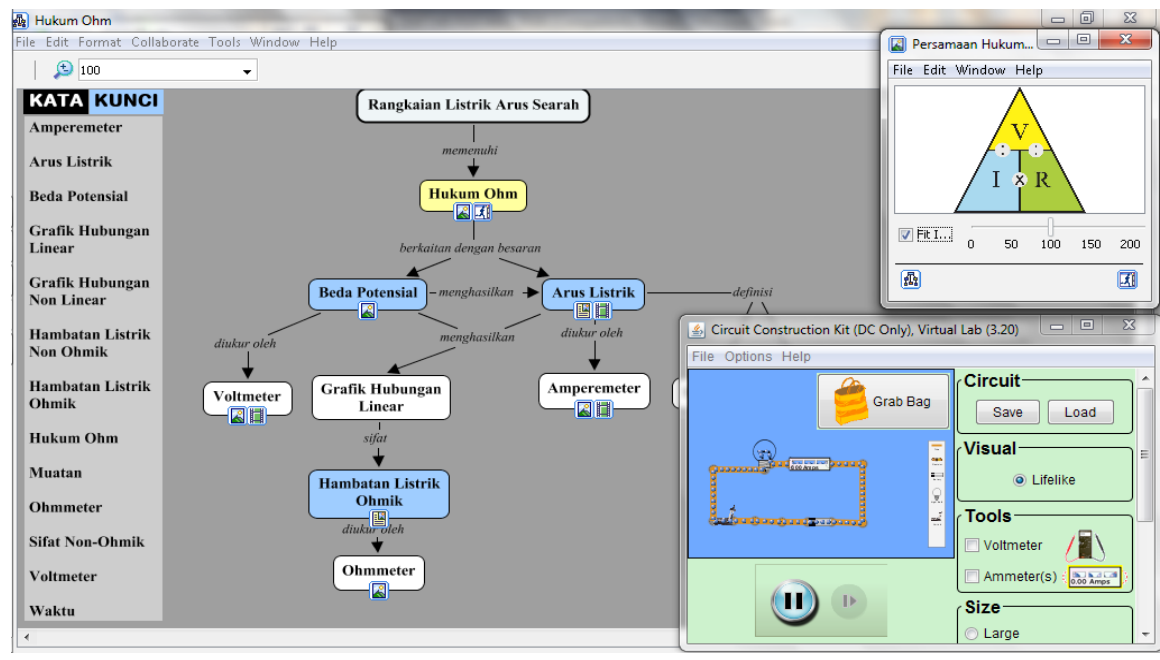

Gambar 1

Contoh Peta Konsep yang Terintegrasi dengan Media Gambar dan Virtual Laboratory pada Konsep Listrik Arus Searah

belajar yang lebih bermakna melalui pembelajaran ini.

Berdasarkan permasalahan serta pernyataan yang telah diungkapkan, peneliti bermaksud melakukan penelitian lebih lanjut, mengenai perbedaan peningkatan kemampuan kognitif dan daya tahan retensi siswa, antara kelas yang menggunakan model pembelajaran inkuiri terbimbing berbantuan CmapTools dengan kelas yang menggunakan model pembelajaran inkuiri terbimbing tanpa bantuan CmapTools. Hal ini dilakukan dalam rangka mengetahui seberapa besar peran model pembelajaran inkuiri terbimbing dan peta konsep menggunakan CmapTools dalam meningkatkan kemampuan kognitif dan 
mempertahankan retensi siswa pada materi ajar listrik arus searah.

\section{METODE PENELITIAN}

Metode penelitian yang digunakan dalam penelitian ini adalah metode eksperimen semu (quasi experiment) dengan desain penelitian yang digunakan dalam penelitian ini ialah randomized control group pretestposttest design (Fraenkel dan Wallen, 1990). Penelitian ini mempergunakan dua kelas yang diambil secara cluster random sampling dari kelas $\mathrm{X}$ yang berjumlah delapan kelas, satu kelas akan menjadi satu kelompok kontrol dan satu kelas lainnya menjadi kelompok eksperimen. Kelompok eksperimen mendapatkan perlakuan pembelajaran dengan menggunakan model pembelajaran inkuiri terbimbing berbantuan CmapTools, sedangkan kelompok kontrol mendapatkan perlakuan pembelajaran dengan menggunakan model pembelajaran inkuiri terbimbing tanpa bantuan CmapTools. Pola randomized control group pretest-posttest design ditunjukkan pada Tabel 1.

Tabel 1

Desain Penelitian Randomized Control Group Pretest - Posttest Design

\begin{tabular}{cccc}
\hline Kelompok & Pretest & Treatment & Posttest \\
\hline Eksperimen & $\mathrm{T}_{1}$ & $\mathrm{X}_{1}$ & $\mathrm{X}_{2}$ \\
\hline Kontrol & $\mathrm{T}_{1}$ & $\mathrm{~T}_{2,2}, \mathrm{~T}_{23}, \mathrm{~T}_{23}$ \\
\hline \multicolumn{4}{c}{ (Fraenkel dan Wallen, 2007) } \\
Keterangan: \\
$\mathrm{T}_{1}=$ pretest untuk mengukur kemampuan kognitif siswa. \\
$\mathrm{X}_{1}=$ treatment berupa penerapan model pembelajaran inkuiri terbimbing berbantuan CmapTools. \\
$\mathrm{X}_{2}=$ treatment berupa penerapan model pembelajaran inkuiri terbimbing. \\
$\mathrm{T}_{2.1}=$ posttest pertama untuk mengukur kemampuan kognitif siswa. \\
$\mathrm{T}_{2.2}=$ posttest kedua untuk mengukur kemampuan kognitif siswa. \\
$\mathrm{T}_{2.3}=$ posttest ketiga untuk mengukur kemampuan kognitif siswa.
\end{tabular}

Instrumen yang diberikan ketika posttest $\left(\mathrm{T}_{2}\right)$ sama dengan pretest $\left(\mathrm{T}_{1}\right)$. Instrumen yang digunakan sebagai pretest dan posttest dalam penelitian ini merupakan instrumen untuk mengukur kemampuan kognitif siswa yang terdiri dari 33 butir soal pilihan ganda yang meliputi empat dari enam ranah kemampuan kognitif Bloom yang telah direvisi Anderson dan Krathwohl (2001), yaitu hafalan (remember/C1), pemahaman (understand/C2), penerapan (apply/C3), dan analisis (analyze/C4). Instrumen tes telah diuji kelayakannya dengan reliabilitas tes 0,79 dan kriteria tinggi (Arikunto, 2007). Adapun pengulangan posttest sebanyak tiga kali dimaksudkan untuk mengukur daya tahan retensi siswa dengan jangka waktu satu pekan, baik untuk jangka waktu posttest pertama ke posttest kedua ataupun dari posttest kedua ke posttest ketiga.

Analisis terhadap perbandingan kemampuan kognitif antara kelas eksperimen dan kelas kontrol dilakukan dengan melakukan uji beda rata-rata (uji hipotesis) pada $\mathrm{N}$-gain kemampuan kognitif siswa yang sebelumnya telah diuji normalitas dan homogenitasnya. Pengujian beda rata-rata ini dilakukan menggunakan bantuan piranti lunak pengolah data IBM SPSS Statistics 20. Sedangkan, analisis terhadap daya tahan retensi siswa dilakukan dengan melihat skor rata-rata penurunan retensi siswa untuk masingmasing kelas dari posttest 1 ke posttest 3 .

\section{HASIL PENELITIAN DAN PEMBAHASAN}

\section{1) Peningkatan kemampuan kognitif siswa}

Perbandingan kemampuan kognitif siswa pada materi ajar listrik arus searah antara kelas eksperimen dan kelas kontrol dapat dilihat pada Tabel 2 . 
Tabel 2

Rekapitulasi Skor Rata-Rata Pretest, Posttest 1, dan $<\mathrm{g}>$ Kemampuan Kognitif Siswa Kelas Eksperimen dan Kelas Kontrol

\begin{tabular}{|c|c|c|c|c|c|c|c|}
\hline Kelas & Tes & Xideal & Xmin & $\mathrm{Xmax}$ & $\bar{X}$ & G & $<\mathrm{g}>$ \\
\hline \multirow{3}{*}{ Eksperimen } & Pretest & 1 & 0,00 & 0,52 & 0,27 & \multirow{2}{*}{0,50} & \multirow{2}{*}{0,68} \\
\hline & Posttest 1 & 1 & 0,58 & 0,94 & 0,76 & & \\
\hline & Kriteria Peningkatan & & & & & & sedang \\
\hline \multirow{3}{*}{ Kontrol } & Pretest & 1 & 0,00 & 0,48 & 0,25 & \multirow{2}{*}{0,41} & \multirow{2}{*}{0,54} \\
\hline & Posttest 1 & 1 & 0,36 & 0,88 & 0,66 & & \\
\hline & Kriteria Peningkatan & & & & & & sedang \\
\hline
\end{tabular}

Perbedaan peningkatan kemampuan kognitif secara keseluruhan antara kelas eksperimen dan kelas kontrol digambarkan pada Gambar 2.

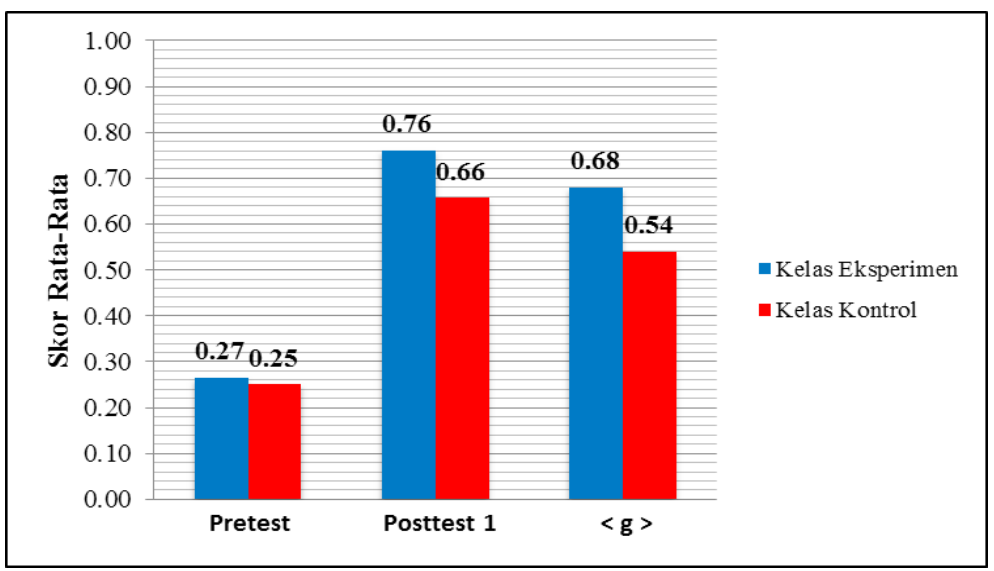

Gambar 2

Skor Rata-Rata Pretest, Posttest 1, dan $<\mathrm{g}>$ Kemampuan Kognitif Siswa Kelas Eksperimen dan Kelas Kontrol

Adapun perbedaan peningkatan kemampuan kognitif, digambarkan pada gambar 3. kognitif antara kedua kelas pada setiap ranah

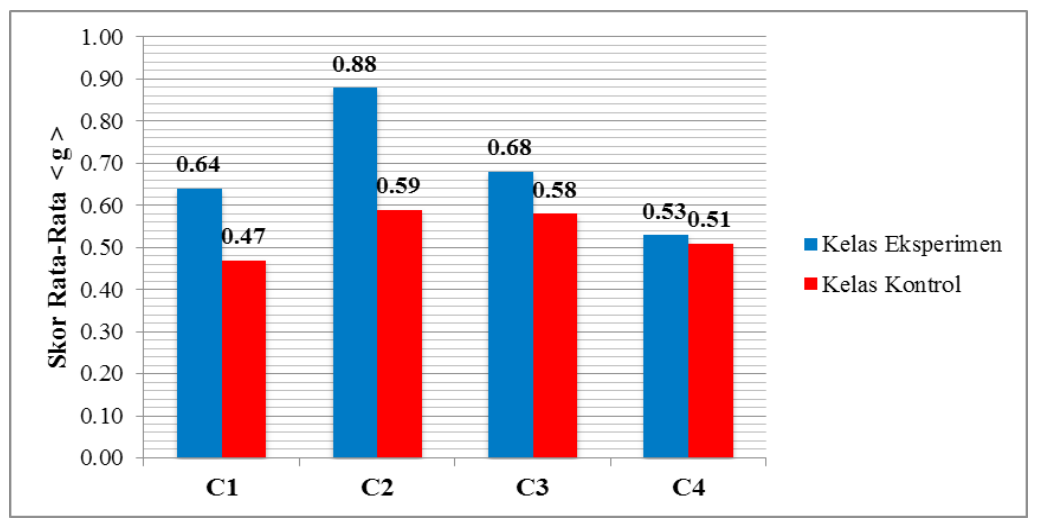

Gambar 3

Skor Rata-Rata Gain yang Dinormalisasi Kemampuan Kognitif Siswa

Kelas Eksperimen dan Kelas Kontrol pada Setiap Ranah Kognitif

Berdasarkan diagram pada gambar 2 dapat terlihat bahwa perolehan skor rata-rata gain yang dinormalisasi $<\mathrm{g}>$ untuk kedua kelas termasuk kriteria sedang. Hal ini disebabkan keterlaksanaan model pembelajaran tidak terlaksana dengan maksimal (kriteria hampir seluruh kegiatan terlaksana). Namun demikian, secara kuantitas peningkatan kemampuan kognitif yang diperoleh siswa pada kelas eksperimen terlihat lebih tinggi 
dibandingkan dengan siswa pada kelas kontrol.

Hasil pengujian beda rata-rata (uji hipotesis) terhadap skor rata-rata gain yang dinormalisasi $<\mathrm{g}>$ dapat disimpulkan bahwa, pada taraf kepercayaan 0,95 (signifikansi 0,05) penggunaan model pembelajaran inkuiri terbimbing berbantuan CmapTools secara signifikan dapat lebih meningkatkan kemampuan kognitif siswa pada materi ajar listrik arus searah dibandingkan dengan penggunaan model pembelajaran inkuiri terbimbing tanpa bantuan CmapTools.

Hasil pengolahan dan analisis data di atas menunjukkan bahwa penerapan model pembelajaran inkuiri terbimbing berbantuan Cmap Tools lebih efektif dalam meningkatkan kemampuan kognitif siswa dibanding penerapan model pembelajaran inkuiri terbimbing tanpa bantuan CmapTools.

Lebih efektifnya model pembelajaran inkuiri terbimbing berbantuan CmapTools dibandingkan dengan pembelajaran inkuiri terbimbing tanpa bantuan CmapTools, sejalan dengan kelebihan dari pembelajaran inkuiri terbimbing berbantuan CmapTools. Menurut Dahar (1996), belajar melalui proses mencari dan menemukan (inkuiri) memungkinkan siswa untuk menggunakan segala potensinya, terutama proses mentalnya untuk menemukan suatu konsep atau prinsip. Dengan demikian, dapat disimpulkan bahwa pembelajaran inkuiri terbimbing merupakan model pembelajaran yang sesuai dengan hakikat manusia untuk selalu mencari pengetahuan secara aktif. Selain itu, dengan model pembelajaran inkuiri terbimbing, materi pelajaran yang didapatkan siswa akan lebih tahan lama, mudah diingat, lebih mudah diaplikasikan pada kondisi yang berbeda, dapat memunculkan motivasi belajar, dapat melatih kecakapan berpikir secara terbuka, dapat meningkatkan penguasaan konsep, mengembangkan sikap ilmiah, dan dapat mengembangkan pemahaman siswa yang mendalam tentang konsep sains (Bruner dalam Dahar, 1989: 103; Pratt dan Hacket dalam John W McBride et all., 2004: 435; Paul Eggen dan June Main 2001: vii; Tapilouw. dkk. 2009: 121). Hal ini pula yang menyebabkan peningkatan kemampuan kognitif untuk ranah pemahaman (C2) pada kedua kelas mengalami peningkatan yang lebih tinggi dibandingkan pada ranah hafalan (C1), ranah penerapan (C2), ataupun ranah analisis (C3) (lihat Gambar 3).

Adapun hadirnya peta konsep berbantuan CmapTools yang telah diintegrasikan dengan berbagai bentuk bahan ajar (teks, gambar, animasi, video, dll) dalam pembelajaran inkuiri terbimbing ini merupakan bantuan media yang berfungsi untuk memperjelas, mempertegas, memberikan pengulangan, dan penguatan terhadap konsep yang diperoleh siswa.

Menurut Brinkmann, Kinchin, dan Alias (2005), peta konsep yang dibuat oleh siswa dapat digunakan sebagai alat untuk

Tabel 3

Rekapitulasi Skor Rata-Rata Posttest 1, Posttest 2, dan Posttest 3

Kemampuan Kognitif Siswa Kelas Eksperimen dan Kelas Kontrol

\begin{tabular}{lcccccc}
\hline Kelas & \multicolumn{1}{c}{ Tes } & Xideal & Xmin & Xmax & $\bar{X}$ & $\begin{array}{c}\text { Penurnan } \\
\text { Retensi }\end{array}$ \\
\hline \multirow{2}{*}{ Eksperimen } & Posttest 1 & 1 & 0,58 & 0,94 & 0,76 & \multirow{2}{*}{0,10} \\
\cline { 2 - 6 } & Posttest 2 & 1 & 0,55 & 0,85 & 0,70 \\
\cline { 2 - 6 } Kontrol & Posttest 3 & 1 & 0,52 & 0,82 & 0,66 & \\
\cline { 2 - 6 } & Posttest 1 & 1 & 0,36 & 0,88 & 0,66 & \multirow{2}{*}{0,18} \\
\cline { 2 - 6 } & Posttest 2 & 1 & 0,30 & 0,79 & 0,55 \\
\hline
\end{tabular}




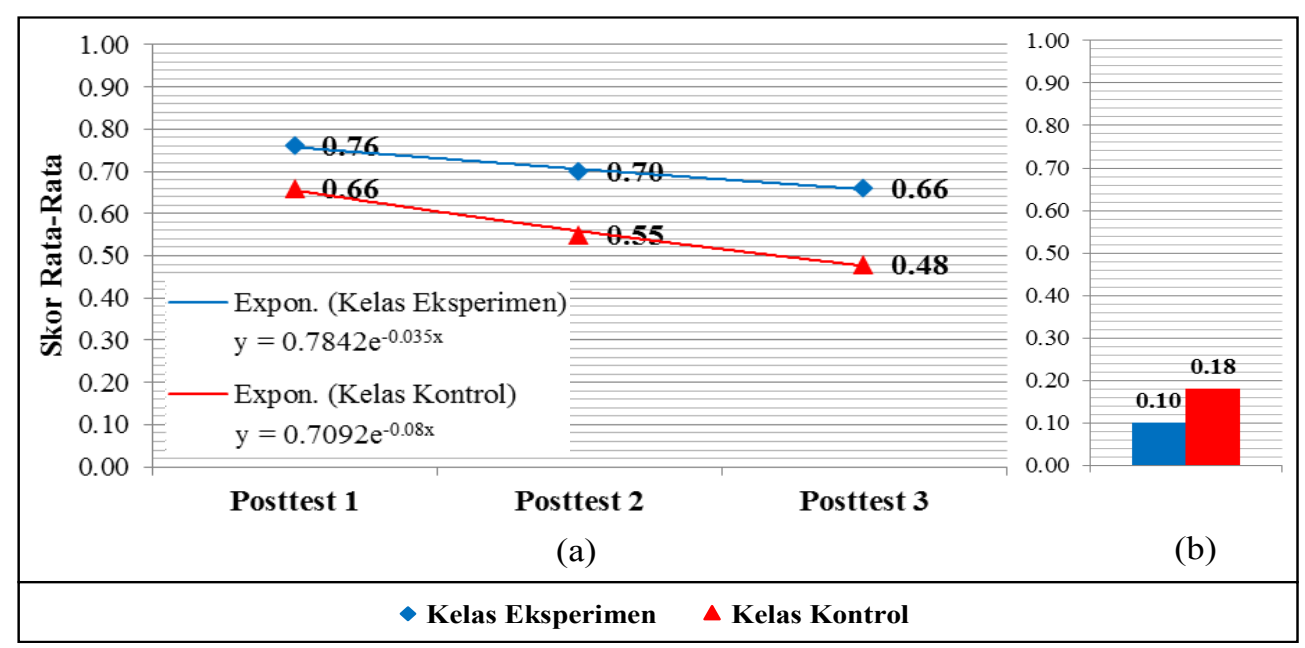

Gambar 4

Perbandingan Retensi Siswa pada Setiap Posstest, (b) Perbandingan Skor Rata-Rata Penurunan Retensi Siswa dari Posttest 1 ke Posttest 3

menciptakan pemahaman yang lebih baik (sebut kemampuan kognitif). Selain itu, peta konsep yang dibuat siswa juga dapat digunakan sebagai alat penelitian yang dapat digunakan untuk meningkatkan pemahaman konsep (Novak dan Gowing, 2004). Alasan inilah yang menyebabkan peningkatan kemampuan kemampuan kognitifuntuk ranah pemahaman (C2) pada kelas eksperimen lebih tinggi dibandingkan kelas kontrol (lihat Gambar 3).

\section{2) Daya tahan retensi siswa}

Berikut skor rata-rata posttest 1 , posttest 2 , dan posttest 3 yang diperoleh siswa pada kelas eksperimen dan kelas kontrol.

Berikut digambarkan perbandingan grafik kecenderungan (trendline) dari penurunan retensi siswa mengenai materi ajar listrik arus searah antara kelas eksperimen dan kelas kontrol secara eksponensial.

Berdasarkan Gambar 4, tampak kemampuan kognitif siswa untuk kelas eksperimen dan kelas kontrol mengalami penurunan pada posttest 2 dan posttest 3 dengan beracuan pada skor yang diperoleh masing-masing kelas pada posttest 1 . Hal ini menunjukkan bahwa retensi siswa pada kelas eksperimen dan kelas kontrol mengalami penurunan. Penurunan retensi yang dialami siswa pada kelas eksperimen relatif lebih rendah dari penurunan retensi yang dialami siswa pada kelas kontrol. Pada kelas eksperimen skor rata-rata Posttest 1, Posttest 2, dan Posttest 3 masing-masing sebesar $0,76,0,70$, dan 0,66. Adapun skor rata-rata Posttest 1, Posttest 2, dan Posttest 3 untuk kelas kontrol masing-masing sebesar 0,66, 0,55, dan 0,48. Berdasarkan data ini dapat kita peroleh penurunan skor rata-rata posttest 3 dan posttest 1 untuk kelas eksperimen dan kelas kontrol masing-masing sebesar 0,10 dan 0,18 . Artinya, siswa pada kelas eksperimen mengalami penurunan retensi (daya ingat) mengenai materi ajar listrik arus searah sebesar $13 \%$, sedangkan siswa pada kelas kontrol mengalami penurunan retensi (daya ingat) mengenai materi ajar listrik arus searah sebesar $27 \%$.

Hasil pengolahan dan analisis data di atas menunjukkan bahwa penerapan model pembelajaran inkuiri terbimbing berbantuan CmapTools lebih baik dalam mempertahankan retensi siswa dibanding penerapan model pembelajaran inkuiri terbimbing tanpa bantuan CmapTools.

Lebih baiknya model pembelajaran inkuiri terbimbing berbantuan CmapTools dalam mempertahankan retensi siswa, dapat dijelaskan berdasarkan tahapan-tahapan model pembelajarannya itu sendiri. Dalam pembelajaran inkuiri terbimbing berbantuan 
CmapTools, tampak beberapa tahapan yang secara mendasar menuntut siswa melakukan rekognisi (pemanggilan kembali) pengetahuan yang telah diperolehnya pada setiap tahapan sebelumnya. Tahapan pertama, yaitu pada tahap pembuatan peta konsep menggunakan CmapTools. Tahapan kedua, yaitu pada saat siswa berusaha menghubungkan sumber bahan ajar, baik berbentuk teks, gambar, video, atau yang lainnya dengan peta konsep yang telah dibuatnya menggunakan CmapTools. Dan tahapan ketiga, yaitu pada saat ditampilkan CmapTools yang telah terintegrasi dengan berbagai sumber bahan belajar sebagai informasi yang dapat digunakan untuk membandingkan, membenarkan dan atau menguatkan pengetahuan yang mereka peroleh dari kegiatan percobaan.

Ketiga tahapan inilah yang menyebabkan retensi siswa pada kelas eksperimen dapat lebih bertahan dibandingkan dengan retensi siswa pada kelas kontrol. Hal ini sejalan dengan pemaparan Porter dan Hernacki (2000: 213), bahwa kita akan mengingat informasi dengan sangat baik jika informasi tersebut dicirikan oleh kualitas-kualitas sebagai berikut: (a) Adanya asosiasi indera terutama indera penglihatan. Pengalaman yang melibatkan penglihatan, bunyi, sentuhan, rasa atau gerakan umumnya sangat jelas dalam memori kita; (b) Adanya konteks emosional seperti cinta, kebahagiaan, dan kesedihan; (c) Kualitas yang menonjol atau berbeda; (d) Asosiasi yang intens; (e) Kebutuhan untuk bertahan hidup; (f) Hal-hal yang memiliki keutamaan pribadi; dan (g) Hal-hal yang diulang-ulang.

Selain itu, Novak dan Gowing (2004) menguatkan bahwa, peta konsep yang dibuat siswa juga dapat digunakan sebagai alat penelitian yang dapat digunakan untuk meningkatkan pemahaman konsep dan retensi pengetahuan siswa. Hal ini dikarenakan upaya dalam membuat dan membangun peta konsep menuntut siswa untuk merekognisi ingatan dan pemahaman mereka terhadap berbagai hubungan antara konsep utama dengan beberapa sub-konsep (Inman, Ditson \& Ditson, 1998; Ellis, Al Rudnitsky \& Silverstein, 2004). Hal inilah yang menyebabkan perbandingan yang menonjol antara penurunan retensi siswa kelas eksperimen dan siswa kelas kontrol untuk ranah pemahaman (C2). Pada kelas eksperimen, skor rata-rata penurunan retensi sebesar 5\% sedangkan pada kelas kontrol mencapai $26 \%$.

\section{KESIMPULAN}

Berdasarkan analisis terhadap data hasil penelitian, maka dapat disimpulkan sebagai berikut: (1) Penerapan model pembelajaran inkuiri terbimbing berbantuan CmapTools secara signifikan dapat lebih meningkatkan kemampuan kognitif siswa pada materi ajar listrik arus searah dibandingkan model pembelajaran inkuiri terbimbing tanpa bantuan CmapTools; dan (2) Penerapan model pembelajaran inkuiri terbimbing berbantuan CmapTools dapat lebih mempertahankan retensi siswa pada materi ajar listrik arus searah dibandingkan model pembelajaran inkuiri terbimbing tanpa bantuan CmapTools.

Berdasarkan hasil penelitian, maka peneliti memberikan saran sebagai berikut: (1) Untuk mengantisipasi ketidakterlaksanaan tahapan pembelajaran akibat terbatasnya waktu, maka pembelajaran yang akan diterapkan dalam penelitian sebaiknya disimulasikan atau diujicobakan terlebih dahulu; (2) Guru hendaknya meningkatkan kemampuan dasar dalam mengelola kelas, menampilkan demonstrasi, menyampaikan pertanyaan arahan, memandu eksperimen dan diskusi, serta keterampilan memotivasi siswa; dan (3) Penggunaan CmapTools dan Lembar Kegiatan Siswa (LKS) bentuk terbuka perlu difahamkan terlebih dahulu kepada siswa supaya pembelajaran bisa lebih efektif sesuai dengan yang telah direncanakan. 


\section{DAFTAR PUSTAKA}

Anderson, O. W. and David R. K. (2001). A Taxonomy For Learning, Teaching And Assessing. New York: Longman.

Arikunto, S. (2007). Dasar-dasar Evaluasi Pendidikan. Jakarta: Bumi Aksara.

Depdiknas. (2006). Kurikulum Tingkat Satuan Pendidikan Sekolah Menengah Atas. Jakarta: Depdiknas.

Depdiknas. (2008). Strategi pembelajaran MIPA. Jakarta: Direktorat Tenaga Kependidikan Direktorat Jenderal Peningkatan Mutu Pendidik Dan Tenaga Kependidikan.

Fraenkel, J. R. and Wallen, N. E. (2007). How to Design And Evaluate Reaserch In Education, $6^{\text {th }}$ Edition. Singapore: McGraw-Hill.

Karim, S. et all. (2007). Penerapan Pendekatan Pembelajaran Berbasis Masalah untuk Meningkatkan Penguasaan konsep Fisika serta Mengembangkan Keterampilan Berpikir Tingkat Tinggi dan Kecakapan Ilmiah. Proposal Hibah Kompetitif UPI 2007. Bandung: Tidak diterbitkan.

McBride, J. W. et all. (2004). Using an inquiry approach to teach science to secondary school science teachers. Physics Education Journal. 39 (5), 434-439.

Novak, J. D. and Canas, A. J. (2004). Building on New Constructivist Ideas and CmapTools to Create a New Model for Education1. Institute for Human and Machine Cognition. [Online]: www.ihmc.us. 